\title{
Experimental Parkinsonism Alters Anandamide Precursor Synthesis, and Functional Deficits are Improved by AM404: A Modulator of Endocannabinoid Function
}

\author{
Emilio Fernandez-Espejo',*, Isabel Caraballo', Fernando Rodriguez de Fonseca ${ }^{2}$, Belen Ferrer ${ }^{2}$, \\ Fadwa El Banoua', Juan A Flores' and Beatriz Galan-Rodriguez' \\ 'Departamento de Fisiologia Medica y Biofisica, Universidad de Sevilla, Sevilla, Spain; ${ }^{2}$ Fundacion Carlos Haya, Hospital Carlos Haya, \\ Málaga, Spain
}

\begin{abstract}
Modulation of the endocannabinoid system might be useful in treating Parkinson's disease. Here, we show that systemic administration of $\mathrm{N}$ (4-hydroxyphenyl)-arachidonamide (AM404), a cannabinoid modulator that enhances anandamide (AEA) availability in the biophase, exerts antiparkinsonian effects in 6-hydroxydopamine-lesioned rats. Local injections of AM404 into denervated striata reduced parkinsonian motor asymmetries, these effects being associated with the reduction of $D_{2}$ dopamine receptor function together with a positive modulation of $5-H T_{I B}$ serotonin receptor function. Stimulation of striatal $5-H_{1} T_{I B}$ receptors alone was observed to ameliorate parkinsonian deficits, supporting the fact that AM404 exerts antiparkinsonian effects likely through stimulation of striatal 5-HT IB serotonin receptor function. Hence, modulation of cannabinoid function leading to enhancement of AEA in the biophase might be of therapeutic value in the control of symptoms of Parkinson's disease. On the other hand, reduced levels of $\mathrm{N}$-acyl-transferase (AEA precursor synthesizing enzyme), without changes in fatty acid amidohydrolase (AEA degradative enzyme), were detected in denervated striata in comparison with intact striata. This finding reveals the presence of a homeostatic striatal mechanism emerging after dopaminergic denervation likely tending to enhance low dopamine tone. Neuropsychopharmacology (2004) 29, I I 34- I |42, advance online publication, 10 March 2004; doi: I 0. I038/sj.npp. I 300407
\end{abstract}

Keywords: Parkinson; cannabinoids; dopamine; 6-hydroxydopamine; anandamide

\section{INTRODUCTION}

Brain cannabinoid $\mathrm{CB}_{1}$ receptors are expressed in neural areas that contribute to movement such as the basal ganglia, where their density is high and they colocalize with $\mathrm{D}_{1}$ and $\mathrm{D}_{2}$ dopamine receptors, and $5-\mathrm{HT}_{1 \mathrm{~B}}$ serotonin receptors in medium spiny projection neurons of dorsal striatum (Herkenham et al, 1990, 1991; Surmeier et al, 1996; Tsou et al, 1998; Hermann et al, 2002). It is known that there is a continual intracerebral release of endogenous cannabinoid receptor agonists such as anandamide (AEA) exhibiting neurotransmitter function (Giuffrida et al, 1999; Baker et al, 2000 ), and that the endocannabinoid system is an activitydependent modulator of intrastriatal dopaminergic neurotransmission (Cadogan et al, 1997; Glass et al, 1997; Pertwee, 1999; Giuffrida et al, 1999; Beltramo et al, 2000). Serotonin neurotransmission could also be modulated by the endocannabinoid system, but its interaction with striatal

*Correspondence: E Fernandez-Espejo, Departamento de Fisiologia Medica y Biofisica, Universidad de Sevilla, Av. Sanchez Pizjuan 4, Sevilla E-4I009, Spain, Tel: + 34-954556584, Fax: + 34-95455I769,

E-mail: efespejo@us.es

Received 25 September 2003; revised 23 December 2003; accepted 3I December 2003

Online publication: 9 January 2004 at http://www.acnp.org/citations/ Npp0 I090403444/default.pdf serotonin receptors such as $5-\mathrm{HT}_{1 \mathrm{~B}}$ is not known. Endogenous cannabinoid $\mathrm{CB}_{1}$ activation seems to act as a brake of striatal dopaminergic activity, and it has been proposed that it is a homeostatic counter-regulatory mechanism in the basal ganglia (Rodriguez de Fonseca et al, 1994, 1998; Giuffrida et al, 1999; Beltramo et al, 2000).

The interdependence between striatal $\mathrm{CB}_{1}$ and dopamine receptors has led to propose that $\mathrm{CB}_{1}$ receptor ligands could be of value for improving motor deficits in neurodegenerative diseases such as Parkinson's disease (Glass et al, 1997; Rodriguez de Fonseca et al, 1998; Consroe, 1998). The involvement of the endocannabinoid system in Parkinson's disease is also supported by recent findings describing the upregulation of $\mathrm{CB}_{1}$ receptors in the striatum after dopaminergic denervation, both in animals and humans (Romero et al, 2000; Lastres-Becker et al, 2001), associated with changes in striatal AEA levels. In this context, enhancement of striatal AEA levels caused by a decrease in AEA degradation (Gubellini et al, 2002) or reduction of AEA levels have been reported (Ferrer et al, 2003). Hence, the precise physiological motor role of $\mathrm{CB}_{1}$ upregulation and striatal AEA changes in parkinsonian striata is a matter of controversy.

In the present study, the cannabinoid ligand $\mathrm{N}$-(4hydroxyphenyl)-arachidonamide (AM404) has been tested in a Parkinson's model based on the selective unilateral 
destruction of nigral neurons in rats. AM404 is a modulator of AEA function that enhances AEA availability in the biophase by blocking AEA reuptake and inhibiting fatty acid amidohydrolase (FAAH), AEA degradative enzyme (Beltramo et al, 1997, 2000; Compton and Martin, 1997; Glaser et al, 2003). AM404 also activates vanilloid receptors, and seems to enhance the availability of 2-arachidonoylglycerol as well, another endocannabinoid substance (Zygmunt et al, 2000; Bisogno et al, 2001). The animal model used in this study produces a suitable hemiparkinsonian syndrome (Marshall, 1979; Schwarting and Huston, 1996; Fornaguera et al, 1994; Cenci et al, 2002), and it has been extensively used to monitor the effects of grafts, neuroprotective agents, and the antiakinetic potential of candidate antiparkinsonian drugs (Schwarting and Huston, 1996; Cenci et al, 2002). Considering controversial results on striatal AEA levels after dopaminergic denervation, changes in enzymatic activity of FAAH and $\mathrm{N}$-acyltransferase (NAT, AEA precursor synthesizing enzyme) have also been studied, including an intact group of rats for comparisons, taking into consideration the well-known described effects of brain lesioning on the dynamics of the endogenous cannabinoid system (Hansen et al, 2002).

Here, we show that AM404 ameliorates most antiparkinsonian deficits in parkinsonian rats. Reduced levels of NAT were also detected in the denervated striatum $v s$ intact striata, indicating that AEA neurotransmission appears to be reduced after dopaminergic denervation likely as a homeostatic mechanism tending to enhance low dopamine tone. In this scenario, AM404 enhanced striatal $5-\mathrm{HT}_{1 \mathrm{~B}}$ serotonin receptor function. Direct stimulation of $5-\mathrm{HT}_{1 \mathrm{~B}}$ receptors was also observed to improve striatal motor function, supporting the fact that AM404 might ameliorate functional deficits in parkinsonian rats through enhancement of striatal $5-\mathrm{HT}_{1 \mathrm{~B}}$ serotonin receptor function.

\section{MATERIALS AND METHODS}

\section{Subjects}

Male Wistar rats (275-325 g) from the breeding colony of the Faculty of Medicine of the University of Seville, Spain were used. Laboratory temperature was kept at $22 \pm 1^{\circ} \mathrm{C}$, and a $12 \mathrm{~h}$ light-dark cycle (lights on at 0800) was maintained throughout the experiment. Food (lab chow) and water were available ad lib.

\section{Unilateral 6-Hydroxydopamine-Induced Nigra Lesion}

At $30 \mathrm{~m}$ before 6-hydroxydopamine (6-OHDA, RBI) infusion, rats were injected with the antibiotic ceftriazone ( $10 \mathrm{mg} / 0.3 \mathrm{ml}$ i.m.) and desipramine ( $15 \mathrm{mg} / \mathrm{kg}$ IP, Biolink) in order to protect noradrenergic terminals from 6-OHDA toxicity. Rats were anesthetized with chloral hydrate (425 mg/kg i.p.) and placed in a Kopf stereotaxic apparatus. Saline solution $(1.2 \mu \mathrm{l}$ per site) containing 6-OHDA $(5 \mu \mathrm{g} / \mu \mathrm{l}$, free base) and $0.2 \%$ ascorbic acid (Sigma) was injected over 5 min with a blunted 30-gauge cannula at the following coordinates: $\mathrm{AP}=-5.2,-5.4, \mathrm{~L}=-2.2$, and $\mathrm{V}=-8.2 \mathrm{~mm}$ (substantia nigra (SN), Paxinos and Watson, 1997). Control rats followed the same protocol except that the injected solution lacked 6-OHDA.

\section{Guide Cannula Surgery and Intracerebral Injection}

Anesthetized rats were given prophylactic ceftriazone and placed in a Kopf stereotaxic apparatus. A hole was drilled over the injection site, and a 22-gauge stainless-steel guide cannula (small parts) was aimed $2 \mathrm{~mm}$ above the dorsal striatum $(\mathrm{AP}=+0.5, \mathrm{~L}= \pm 3$, and $\mathrm{V}=-5.5$ ) (Paxinos and Watson, 1997). The guide cannula was fastened to the skull with stainless-steel screws (small parts) and dental cement, and was fitted with a 30-gauge stainless-steel obturator, protruding $1.5 \mathrm{~mm}$ out of the tip of the guide cannula (small parts). Rats were allowed to recover $48 \mathrm{~h}$ after surgery. Injections were performed in the home cage after removing the obturator cannula, which was replaced by a 30 -gauge stainless-steel internal cannula (Small Parts) connected to a Hamilton syringe and a delivery pump (Stoelting). Solutions were slowly injected over $5 \mathrm{~min}$, and afterwards the internal cannula was carefully removed and the obturator cannula was replaced. After completion of all the experiments, brains were removed and sectioned. Cannula placements were verified under microscope and were mapped onto a stereotaxic atlas (Paxinos and Watson, 1997), and confirmed to be in the dorsal striatum.

\section{Chemicals and Doses}

AM404 and AM251 were provided by Tocris (Biogen). D-amphetamine was provided by RBI. AM404 was dissolved in $30 \%$ ethanol $/ 70 \%$ distilled water. AM251 was dissolved in $50 \%$ DMSO $/ 50 \%$ distilled water. D-amphetamine $(5 \mathrm{mg} / \mathrm{kg})$ was dissolved in saline solution $(0.9 \% \mathrm{NaCl})$. With regard to dopamine receptor ligands, SKF 38393 ( $\mathrm{D}_{1}$ dopamine receptor agonist), SCH $23390 \quad\left(\mathrm{D}_{1}\right.$ dopamine receptor antagonist), and quinpirole ( $\mathrm{D}_{2}$ dopamine receptor agonist) were provided by Tocris. Eticlopride $\left(D_{2}\right.$ dopamine receptor antagonist) was provided by Sigma. All these dopaminergic ligands are highly selective (Seeman and Van Tol, 1994; Sullivan et al, 1998). SKF 38393 and SCH 23390 were dissolved in double distilled water. Eticlopride and quinpirole were dissolved in $30 \%$ ethanol/70\% distilled water. For serotonergic receptor ligands, 8-OH-DPAT $\left(5-\mathrm{HT}_{1 \mathrm{~A}}\right.$ receptor agonist), CGS12066B (5- $\mathrm{HT}_{1 \mathrm{~B}}$ agonist), NAN190 (5- $\mathrm{HT}_{1 \mathrm{~A}}$ antagonist), and GR55562 (5- $\mathrm{HT}_{1 \mathrm{~B}}$ antagonist) were provided by Tocris. All these serotonergic compounds are highly selective (Middlemiss and Fozard, 1983; Neale et al, 1987; Glennon et al, 1988; MacLean et al, 1996). 8-OHDPAT, CGS12066B, and NAN190 were dissolved in double distilled water, and GR55562 was dissolved in 30\% ethanol/ $70 \%$ distilled water. The corresponding vehicle was used for the control group in every treatment.

AM404 was injected at systemic doses of 0,1 , and $5 \mathrm{mg} / \mathrm{kg}$ i.p. (v/w, $1 \mathrm{ml} / \mathrm{kg}$ ); and at intracerebral doses of 0,1 , and $5 \mu \mathrm{g} / \mu \mathrm{l}$ (volume of infusion, $1.5 \mu \mathrm{l}$ ). AM251 was coinjected with AM404 at systemic doses of 0,1 , and $5 \mathrm{mg} / \mathrm{kg}$ or at intracerebral doses of 0,1 , and $5 \mu \mathrm{g} / \mu \mathrm{l}$ (1:1 cotreatment). For intrastriatal infusions of dopaminergic ligands (volume, $1.5 \mu \mathrm{l}), \mathrm{SCH}-23390$ and eticlopride were injected at 0,1 , and $2 \mu \mathrm{g} / \mu \mathrm{l}$ doses (free base, SCH-23390, 4.6 and $9.1 \mathrm{nmol}$; eticlopride, 2.6 and $5.3 \mathrm{nmol}$ ), and SKF-38393 and quinpirole were each administered at $0,0.5$, and $1 \mu \mathrm{g} / \mu \mathrm{l}$ doses (free base, SKF-38393, 2.2 and $4.4 \mathrm{nmol}$; quinpirole, 2.9 and $5.8 \mathrm{nmol}$ ). With regard to intrastriatal infusions of 
serotonergic ligands, 8-OH-DPAT and CGS12066B were administered at 0, 5, and $10 \mathrm{nmol}$ (free base), and NAN190 and GR55562 were injected at 0,4 , and $8 \mathrm{nmol}$. For cotreatments, AM404 was injected at $1 \mu \mathrm{g} / \mu \mathrm{l}(1.5 \mu \mathrm{l})$.

\section{Groups and General Protocol}

For systemic administration studies, animals belonged to two groups: (i) hemiparkinsonian rats $(n=18)$ and (ii) sham-lesioned control rats $(n=10)$. All parkinsonian rats presented a strongly positive response to amphetamine ( $>420$ turns/h) 15 days after lesion. At 1 month after lesion, the $\mathrm{CB}_{1}$ ligand was administered every day following a 'Latin-square-' type design. With regard to intracerebral injections, two groups of parkinsonian rats were studied, each group with a cannula aimed at the left $(n=10)$ or right $(n=9)$ dorsal striatum. At 1 month after lesion, AM404 was administered daily through the cannula at several doses following a 'Latin-square-' type design, and changing the initial dose for every rat, immediately before amphetamine (one test per day). Different groups of parkinsonian rats were also subjected to intrastriatal injections of dopaminergic ligands alone or in combination with AM404 ( $D_{1}$ receptor ligands, $n=9 ; \mathrm{D}_{2}$ receptor ligands, $\left.n=10\right)$, or serotonergic ligands alone or in combination with AM404 (5- $\mathrm{HT}_{1 \mathrm{~A}}$ receptor ligands, $n=9 ; 5-\mathrm{HT}_{1 \mathrm{~B}}$ receptor ligands, $n=10)$, following a 'Latin-square-' type design, and changing the initial dose for every rat. If dopaminergic or serotonergic ligands were coinjected with AM404, they were administered 5 min before AM404 infusion.

\section{Behavioral Tests and Statistics}

For behavioral study, we followed a methodology described previously (Ungerstedt and Arbuthnott, 1970; Marshall, 1979; Schwarting and Huston, 1996; Fornaguera et al, 1994; Espejo et al, 1998). Thus, locomotor directional bias was evaluated by quantifying either ipsiversive rotations induced by amphetamine ( $5 \mathrm{mg} / \mathrm{kg}$ i.p.), from 30 to $90 \mathrm{~min}$ after amphetamine. Akinesia was quantified in a $10-\mathrm{min}$ open-field test $\left(1 \times 1 \mathrm{~m}^{2}\right)$ through distance travelled $(\mathrm{cm})$. Sensorimotor orientation was evaluated by means of the odor test (Stricker and Zigmond, 1986). A probe with the tip impregnated in amoniac was approached from the right side near the nose, and the latency for shaking the head off the probe was quantified. Forelimb asymmetry was evaluated by the cylinder test (Kirik et al, 2000), where the animal is allowed to move freely in a transparent cylinder $\left(50 \times 30 \mathrm{~cm}^{2}\right)$ until it has displayed 20 rearing postures. The numbers of left and right forepaw contacts are counted, and the data are presented as the percentage of right forepaw contacts (right paw use ratio). Hemiparkinsonian rats with lesion in the left $\mathrm{SN}$ present a significant impairment in the contralateral (right) paw use.

With regard to intracerebral injections, the number of amphetamine-induced turning was considered as the dependent variable in order to detect changes in the functional activity of basal ganglia. Percent changes in the number of turnings with respect to vehicle-treated rats were measured, considering vehicle-treated rats as percentage 0 (positive values, reduction; negative values, enhancement of turning).
Behavioral data after systemic injections were studied by two-way ANOVA (group, between variable; drug dose, within variable), followed by one-way ANOVA (drug dose as within variable) and post hoc Newman-Keuls tests. Behavioral data after intracerebral injections were analysed by using one-way ANOVA (treatment as between variable) followed by post hoc Newman-Keuls test for comparison between groups. When variance was not homogeneous, data were logarithmically $(\log (x)]$ transformed prior to analysis. Student's $t$-test (independent measures) were used for comparison between groups at the same dose point. Experiments were performed according to the animal care guidelines of the European Communities Council (86/609/ EEC).

\section{Immunohistochemistry and Cell Counting}

Half of the rats subjected to systemic injections were killed by decapitation and brains carefully removed. Brains were postfixed and stored in $4 \%$ paraformaldehyde in phosphate buffer (PB) $0.1 \mathrm{M}(\mathrm{pH} 7.2-7.4)$ at $4^{\circ} \mathrm{C}$. Coronal brain sections ( $50 \mu \mathrm{m}$ thick) were cut on a vibratome and collected in PBS. Thereafter, endogenous peroxidase activity was quenched by placing sections into $0.3 \% \mathrm{H}_{2} \mathrm{O}_{2}$ in 0.05 Tris buffer $(\mathrm{pH}=7.6)$ for $2 \mathrm{~h}$. Then sections were incubated in PBS/ $0.1 \%$ Triton X-100 (PBS-T) with $10 \%$ FCS (Vector) and BSA ( $1 \mathrm{mg} / \mathrm{mgl}$, Sigma) for $4 \mathrm{~h}$ to block nonspecific sites. Sections were incubated overnight with rabbit anti-tyrosine-hydroxylase polyclonal antibody (1:1000, Chemicon) in PBS-T. After washing they were incubated for $1 \mathrm{~h}$ with anti-rabbit biotin-conjugated antibody (1:200, Chemicon). Then, sections were incubated with the $\mathrm{ABC}$ kit, and specifically bound antibody were revealed by using 3.3'-diaminobencidine tetrahydrochloride (Sigma) as chromogen and $0.05 \%$ hydrogen peroxide (Merck). Negative control sections were incubated following the same protocol, with the exception that the primary antibody solution was replaced by a PBS-T solution containing $10 \%$ FCS and BSA $(1 \mathrm{mg} / \mathrm{ml})$. Sections were washed in PBS and mounted on glass slides and coverslipped with DPX. A quantitative assessment of dopaminergic neurons in $\mathrm{SN}$ was carried out to confirm lesion degree. Thus, the number of tyrosine hydroxylase (TH) immunoreactive neurons in the SN pars compacta was assessed by a blinded observer. In all rats 15 consecutive sections were used, and stained neurons in the SN were counted at $\times 4$ magnification $(n=5$ per group), on the basis of Paxinos and Watson (1997). TH positive neurons were counted when displaying a nucleus surrounded by THpositive cytoplasm.

\section{Preparation of Rat Tissue Subcellular Fractions and Enzymatic Activities of FAAH and $N$-Acyltransferase}

For these measures, apart from sham and lesioned rats, a group of intact naive rats was also used for better discernment of enzymatic changes. The brain endogenous cannabinoid system has been involved in inflammatory processes associated with brain lesioning like that associated with craneotomy and cannula implantation (Hansen et al, 2002). Half of the lesioned and sham rats of systemic studies were used for this study. After rapid inspection of cannula location, brain tissues were homogenized in $50 \mathrm{mM}$ 
Tris buffer, $\mathrm{pH} 8$, containing $0.32 \mathrm{M}$ sucrose. Homogenates were centrifuged first at $1000 \mathrm{~g}(5 \mathrm{~min})$, the pellet discarded and the supernatant centrifuged at $45000 \mathrm{~g}(30 \mathrm{~min})$. The pellets obtained were solubilized at $0-4^{\circ} \mathrm{C}$ in Tris buffer. Protein content in the membrane fraction was measured with the Bradford method. All tissue samples and membrane fractions were stored at $-70^{\circ} \mathrm{C}$ until used. Both enzymatic assays were run under conditions that were linear with time and protein concentration. We assayed membrane-bound FAAH activity using arachidonoyl$\left[1-{ }^{3} \mathrm{H}\right]$ ethanolamide as a substrate, and measuring metabolized $\left[{ }^{3} \mathrm{H}\right]$ AEA (as $\left[{ }^{3} \mathrm{H}\right]$ ethanolamine) in the aqueous phase after chloroform extraction, as described (Desarnaud et al, 1995; Rodríguez de Fonseca et al, 2001). Microsomal NAT activity assays were performed using $1,2-\mathrm{Di}\left[{ }^{14} \mathrm{C}\right]$ palmityl$s n$-glycerophosphocholine as substrate (Cadas et al, 1996, 1997). Assays were carried out for $1 \mathrm{~h}$ at $37^{\circ} \mathrm{C}$ in $0.5 \mathrm{ml}$ of Tris buffer $(50 \mathrm{mM}, \mathrm{pH} 8)$, to which we added $0.3 \mathrm{mg}$ protein, $3 \mathrm{mM} \mathrm{CaCl} 2$, and $1 \times 10^{6} \mathrm{dpm}$ radioactive substrates. Parallel incubations carried out in the absence of tissue contained on average $100 \mathrm{dpm} / \mathrm{sample}$; these blank values were subtracted in the calculations of enzyme activity. Incubations were stopped by adding chloroform/ methanol (2:1), and the $N$-acyl PEs were fractionated by column chromatography.

\section{RESULTS}

\section{Induction of Hemiparkinsonism}

Rats were rendered hemiparkinsonian by injecting the toxin 6-OHDA into the left SN. Those animals which showed a strong ipsiversive rotational behavior after the administration of amphetamine ( $>420$ turns/hour), indicative of depletion of more than $85 \%$ of striatal dopamine (Fornaguera et al, 1994), were selected for the study. These animals presented an overt hemiparkinsonian syndrome characterized by drug-induced turning, spontaneous ipsiversive turning, akinesia, contralateral sensorimotor neglect, and forepaw use asymmetry. TH immunohistochemistry indicated that intranigral 6-OHDA injection destroyed $88 \pm 3 \%$ of the TH-containing cell bodies in the affected unilateral site (as measured through cell counting), leaving intact the cells of the contralateral nucleus, and dopaminergic innervation in the corresponding ipsilateral striatum was nearly absent.

\section{Enzymatic Activities of Striatal FAAH and $\mathrm{N}$-Acyltransferase}

As shown in Table 1, in rats with 6-OHDA-induced lesion, striatal NAT enzymatic activity was significantly reduced $v s$ intact (not sham) rats $(p<0.05)$, but no significant changes were observed in FAAH activity. However, sham rats showed enhanced levels of FAAH in both ipsilateral and contralateral striata $(p<0.05) v s$ the remainder groups.

\section{Systemic Administration of AM404}

Following AM404 treatment, two-way ANOVA indicated a significant interaction $(F(2,40)=12.1, p<0.01)$ effects on amphetamine-induced turning. Thus, turning behavior was significantly reduced in parkinsonian rats after $1(48.1 \%$ reduction, $p<0.05)$ and $5 \mathrm{mg} / \mathrm{kg}$ AM404 $(48.7 \%, p<0.05)$. Pretreatment of these rats with AM251 (selective $\mathrm{CB}_{1}$ receptor antagonist, 0,1 , and $5 \mathrm{mg} / \mathrm{kg}$ doses, respectively) eliminated the capacity of AM404 to induce functional changes on drug-induced turning, confirming the existence of a $\mathrm{CB}_{1}$-mediated modulation of the intrastriatal dopaminergic tone (Figure 1).

For spontaneous parkinsonian deficits, one-way ANOVA indicated significant dose effects for akinesia $(F(2$,

Table I Enzymatic Activities of FAAH and NAT in the Brain Membrane Fraction from Intact Animals, Animals with Sham Lesion in the Substantia Nigra (Sham), and Animals Lesioned with 6-OHDA (Lesion)

\begin{tabular}{lllr}
\hline & Intact & Sham & Lesion \\
\hline FAAH (pmol/mg/min) & & & \\
Left striatum & $489 \pm 13$ & $535 \pm 14 *$ & $494.1 \pm 34.5$ \\
Right striatum & $466 \pm 9$ & $529 \pm 10 *$ & $431 \pm 46.2$
\end{tabular}

\section{NAT (pmol/mg/min)}

Left striatum $\quad 502 \pm 29 \quad 466 \pm 133 \quad 310.2 \pm 61^{\#, 0}$

\begin{tabular}{|c|c|}
\hline Right striatum & $472 \pm 64$ \\
\hline
\end{tabular}

Left striatum was the denervated one in lesioned rats. Mean+SEM of at least five samples per group.

$* p<0.05$ vs intact and lesioned rats.

${ }^{\#} p<0.05$ vs intact rats.

${ }^{\circ} p<0.05$ vs corresponding contralateral right striatum.
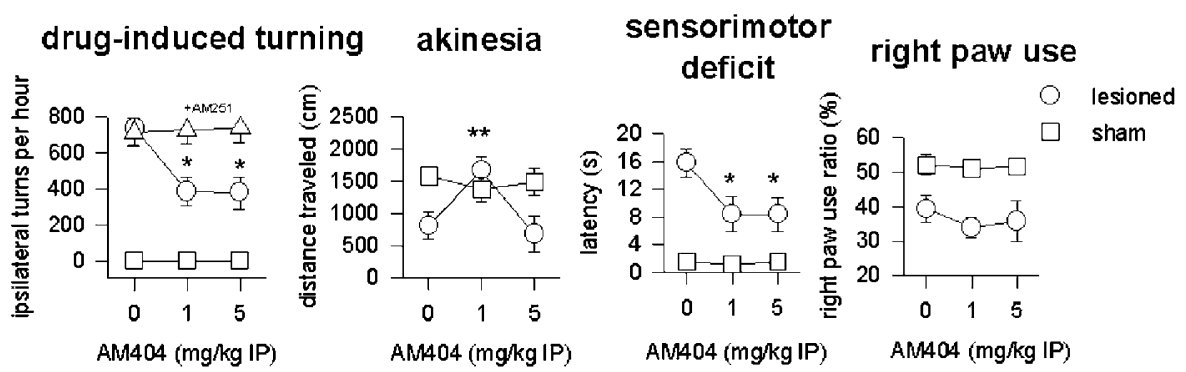

Figure I Effects of AM404 treatment on amphetamine-induced turning, and spontaneous motor and sensorimotor deficits in hemiparkinsonian rats and sham control animals $(\square)$. AM404 ameliorated functional deficits in parkinsonian rats $(\bigcirc)$, as revealed by significant dose effects on amphetamine-induced turning $(p<0.0 \mathrm{I})$, akinesia (distance travelled, $p<0.05$ ), and sensorimotor orientation (odor test, $p<0.0 \mathrm{I})$. Cotreatment with $\mathrm{AM} 25 \mathrm{I}(\mathrm{CB}$ । agonist) eliminated functional effects on turning of AM404 $(\triangle)$. The data show that AM404 is able to improve significantly drug-induced asymmetries and spontaneous functional deficits in hemiparkinsonian rats, except forelimb asymmetry. Mean \pm SEM, $* p<0.05$, *** $p<0.0$ I vs dose 0 (Newman-Keuls test). 
Denervated striatum
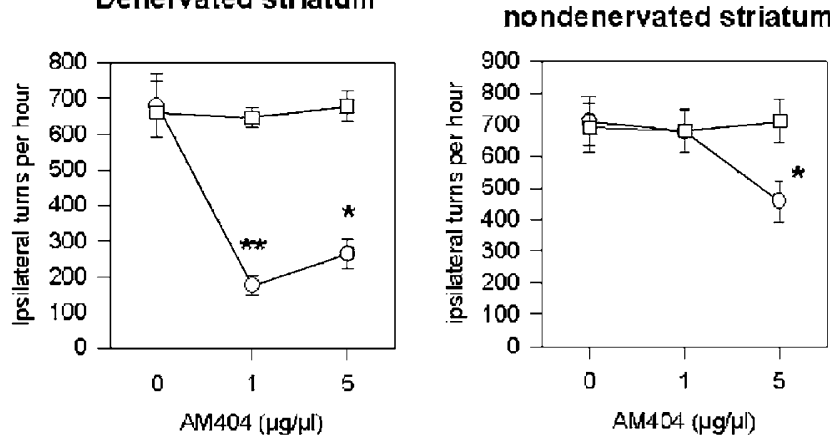

Figure 2 Effects on drug-induced ipsilateral turning (towards the site of nigral lesion) of left (denervated) and right (nondenervated) intrastriatal injections of AM404 in hemiparkinsonian rats $(O)$. Intrastriatal injections into denervated striata significantly attenuated drug-induced turning after I and $5 \mu \mathrm{g} / \mu \mathrm{l}$ AM404. Intrastriatal injections into nondenervated contralateral striata reduced ipsilateral turning after $5 \mu \mathrm{g} / \mu \mathrm{l}$ AM404. Cotreatment with AM25 I ( $C B_{\text {I }}$ agonist) eliminated functional effects on turning of AM25 I ( $\square)$. Mean \pm SEM, ${ }^{*} p<0.05$, ${ }^{*} * p<0.0$ I vs dose 0 of corresponding group (Newman-Keuls test)

$21)=4.56, p<0.05)$ and sensorimotor orientation $(\mathrm{F}(2$, $21)=3.2, p<0.05$ ) after AM404 (Figure 1). Thus, significant amelioration of akinesia occurred following $1 \mathrm{mg} / \mathrm{kg}$ dose $(p<0.01)$, without differences in control rats. Akinesia reappeared after the highest dose tested $(5 \mathrm{mg} / \mathrm{kg}$ i.p.). Sensorimotor orientation was improved after 1 and $5 \mathrm{mg} / \mathrm{kg}$ AM404 $(p<0.05)$. Right forepaw use was not improved following AM404.

\section{Intrastriatal AM404 Acts Reducing $\mathrm{D}_{2}$ Dopamine Receptor Function, and Enhancing 5- $\mathrm{HT}_{1 \mathrm{~B}}$ Serotonin Receptor Function}

With regard to infusions into denervated striata, one-way ANOVA indicated significant dose effects $(F(2,18)=3.2$, $p<0.05$ ) on rotation after AM404 (Figure 2). Thus, turning behavior after amphetamine was significantly reduced following $1(74.2 \%$ reduction, $p<0.01)$ and $5 \mu \mathrm{g} / \mu \mathrm{l}$ AM404 (61.4\% reduction, $p<0.05)$. This effect was blocked after pretreatment with AM251 ( 1 and $5 \mu \mathrm{g} / \mu \mathrm{l}$ doses, respectively). After injections into nondenervated contralateral striatum, only the highest dose of AM404 $(5 \mu \mathrm{g} / \mu \mathrm{l})$ significantly reduced ipsilateral turning $(p<0.05)$, as shown in Figure 2.

As observed in Table 2, one-way ANOVA did not indicate significant treatment effects after local infusions of the $D_{1}$ dopamine receptor ligands in combination with AM404 $(1 \mu \mathrm{g} / \mu \mathrm{l}$; dose exerting maximum effect) in denervated striata. Neither SKF-38393 ( $D_{1}$ receptor agonist) nor SCH23390 $\left(D_{1}\right.$ receptor antagonist) plus AM404 altered functional effects of AM404 or $\mathrm{D}_{1}$ dopaminergic ligands given alone. However, one-way ANOVA indicated significant treatment effects after local infusions of the $D_{2}$ dopamine receptor agonist in combination with AM404. Thus, quinpirole $(2.9$ and $5.8 \mathrm{nmol})$ plus AM404 significantly attenuated functional effects of AM404 or quinpirole alone $(F(4,36)=5.8, p<0.01)$. These findings indicate that
AM404 negatively modulate $\mathrm{D}_{2}$ dopamine receptor function in denervated striata.

As observed in Table 2, one-way ANOVA indicated significant treatment effects after local infusions of $5-\mathrm{HT}_{1 \mathrm{~B}}$, but not $5-\mathrm{HT}_{1 \mathrm{~A}}$, serotonin receptor ligands in combination with AM404. Thus, GR55562 (5- $-\mathrm{HT}_{1 \mathrm{~B}}$ receptor antagonist, 4 and $8 \mathrm{nmol}$ ) plus AM404 significantly antagonized functional effects of both compounds given alone $(\mathrm{F}(4,36)=6.7$, $p<0.01$ ). Interestingly, the number of turnings was further enhanced after cotreatment with GR55562 with respect to vehicle-treated rats. CGS12066B $\left(5-\mathrm{HT}_{1 \mathrm{~B}}\right.$ receptor agonist, 4 and $8 \mathrm{nmol}$ ) plus AM404 significantly enhanced the functional effects of AM404 or CGS12066B alone (F(4, $36)=6.2, p<0.01)$. These findings clearly indicate that AM404 acted stimulating striatal $5-\mathrm{HT}_{1 \mathrm{~B}}$ serotonin receptor function. Stimulation of $5-\mathrm{HT}_{1 \mathrm{~B}}$ serotonin receptors also reduced per se the number of turnings after amphetamine (see Table 2).

\section{Local Injections: Histology}

Only those animals where injection site was found to be correct (within the dorsal striatum) were included for analyses. Inspection of the brain tissue revealed slight evidence of gliosis at the site of injection, although surrounding tissue was generally intact.

\section{DISCUSSION}

\section{NAT Activity is Reduced in Denervated Striata}

The lesion of dopamine neurons of the SN with the toxin 6OHDA resulted in a decrease in the activity of striatal NAT, the enzyme responsible for AEA precursor synthesis, if compared with striata of intact rats. However, no significant changes were observed with respect to sham rats, a result that is otherwise in accordance with Gubellini et al (2002), who reported no changes of NAT activity in 6-OHDAlesioned rats after comparing with sham rats. However, the findings of the present study reveal that NAT activity is actually reduced after denervation if compared with intact striata, representing a novel result. It is possible that sham nigra lesion somehow affected striatal NAT activity explaining the lack of differences with denervated striata. On the other hand, striatal FAAH activity was not affected if compared with intact animals but, again, FAAH activity was reduced if compared with sham rats. This latter result is also in accordance with Gubellini et al (2002), who reported a decrease of FAAH activity after 6-OHDA-induced nigral lesion with respect to sham rats. However, if intact rats are employed for comparisons, no changes in FAAH activity can be observed. It is worth noting that FAAH activity was found to be enhanced in denervated striata of sham rats long after sham lesion in the $\mathrm{SN}$, as well as in contralateral striata. Observed effects on NAT and FAAH activity in sham rats could be accounted for by a long-term overall inflammatory process caused by microcannula lesion because the brain endogenous cannabinoid system has been involved in inflammatory processes associated with brain lesioning and craneotomy (Hansen et al, 2002), suggesting that sham rats do not represent an adequate control group for comparisons. Besides, since striatal FAAH 
Table 2 Effects of Intrastriatal Dopaminergic and Serotonergic Ligands and AM404 on Amphetamine-Induced Turning (Percent Change vs Control) in Parkinsonian Rats

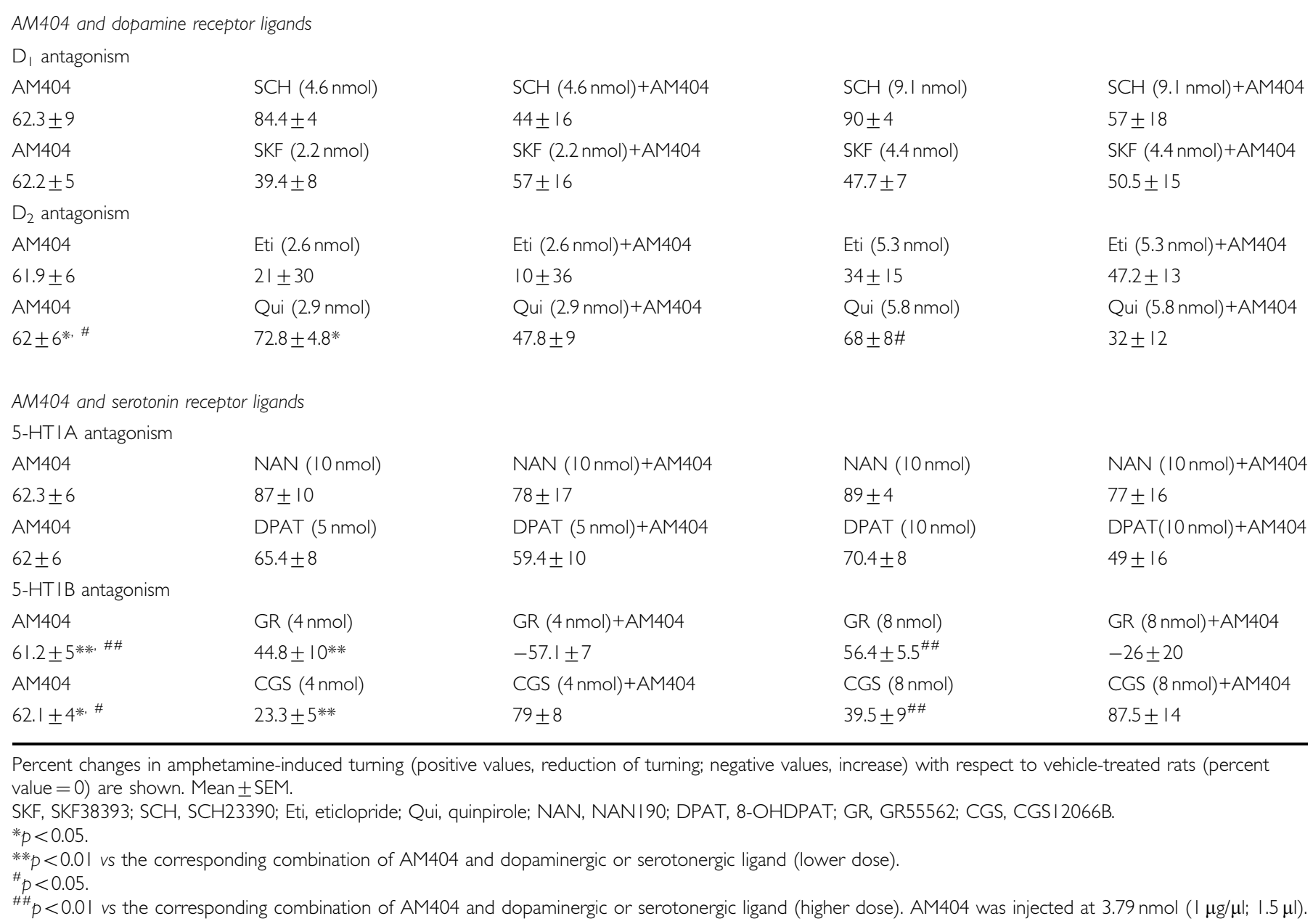

levels were found to be normal in parkinsonian rats $v s$ intact animals, it seems that 6-OHDA-induced dopaminergic degeneration would oppose FAAH activity enhancement caused by inflammation.

To sum up, the findings of the present study allow proposing that striatal NAT activity is actually reduced after 6-OHDA-induced nigra lesion, and FAAH activity is not affected, by using intact rats as controls. As a consequence, the net effect of denervation on AEA availability in the biophase would be a reduction since AEA precursor synthesis is impaired. This conclusion is in line with recent findings by Ferrer et al (2003), but in clear contrast with previous reports showing enhancement of AEA levels in denervated striata in two different models of parkinsonism (Gubellini et al, 2002; Di Marzo et al, 2000). These differences can stem from either the employment of sham rats for comparisons or different procedures to detect levels of AEA. The reduction of NAT enzymatic activity in denervated striata could represent a homeostatic mechanism tending to diminish AEA neurotransmission and to enhance dopamine release, because endogenous AEA activation acts as a brake of striatal dopaminergic activity (Rodriguez de Fonseca et al, 1998). The fact that AEA precursor synthesis is reduced in denervated striatum could be of importance for the development of potential treatments for Parkinson's disease.

\section{Systemic AM404 Exerts Antiparkinsonian Effects}

The data indicated that, within a dose range $(1-5 \mathrm{mg} / \mathrm{kg}$ ), the systemic administration of AM404 induced significant antiparkinsonian effects in parkinsonian rats, as revealed by improvement of akinesia and sensorimotor orientation, as well as a reduction of drug-induced turning. It is worth noting that akinesia did not show significant differences with control rats after $1 \mathrm{mg} / \mathrm{kg}$ dose, indicating that at this dose the cannabinoid ligand was particularly effective in ameliorating this symptom. Since the unilateral 6-OHDAinduced lesion model of Parkinson's diseases in rats parallels the human disorder well (Cenci et al, 2002), these findings are remarkable because sensorimotor orientation and mostly akinesia are difficult to alleviate in human Parkinson's disease, and the antiakinetic effect is highly consistent with an antiparkinsonian profile of AM404.

It is known that cannabinoid agonists have a biphasic effect on movement, with an activational role at low doses 
until immobility and catalepsy appears at higher doses (Fride et al, 1994; Rodriguez de Fonseca et al, 1998; Zimmer et al, 1999; Sañudo-Peña et al, 2000). The results allow proposing that, within a dose range, systemic administration of cannabinoid ligands (such as AM404) enhancing AEA availability through endocannabinoid deactivation (and particularly transport) might be useful for the treatment of Parkinson's disease. It is important to keep in mind that AM404 induced hypokinesia at high doses, which suggests the existence of a 'therapeutic window' and the need of a 'rational' use of this compound as potentially antiparkinsonian tool. However, further clinical research is needed on this topic since the findings of the present study refer to an animal model of parkinsonism and not to an actual human syndrome.

\section{Intrastriatal AM404 Improves Motor Deficits Through Enhancement of 5-HT ${ }_{1 \mathrm{~B}}$ Serotonin Receptor Function}

In order to further analyze AM404-mediated action within the dorsal striatum, regional injections were performed into this structure, where $\mathrm{CB}_{1}$ receptors are known to be highly expressed (Rodriguez de Fonseca et al, 1998). Regional injections induced different and stronger effects on denervated basal ganglia circuit than in nondenervated one, in accordance with previous data where intranigral cannabinoid agonists were found to produce more vigorous turning behavior in 6-OHDA-lesioned rats than in nonlesioned animals (Sañudo-Peña et al, 1996, 1998). With regard to nondenervated circuit, basal ganglia motor function was reduced after the highest AM404 dose as revealed by reduced ipsilateral rotation. This fact could be explained by a negative modulation of dopamine neurotransmission after AM404, thereby reducing the dopamine disbalance between both striata (Cadogan et al, 1997; Glass et al, 1997; Rodriguez de Fonseca et al, 1994, 1998; Pertwee, 1999; Giuffrida et al, 1999; Beltramo et al, 2000). However, parkinsonian asymmetries were also reduced after AM404 injections into denervated striata, indicating the participation of different mechanisms. Besides, rotation was reduced in a dose-dependent manner, pointing to a critical role for dorsal striatum in motor effects following systemic AM404 in parkinsonian rats. Functional effects of AM404 in denervated striata could also be related to the upregulation of $\mathrm{CB}_{1}$ receptors, a phenomenon that has been described both in animals and humans (Romero et al, 2000; LastresBecker et al, 2001).

Following injections into denervated striata, the findings revealed that AM404 acted reducing $\mathrm{D}_{2}$ dopamine receptor function, because motor actions of the $\mathrm{D}_{2}$ receptor agonist quinpirole were diminished after coinjection with AM404. In this context, AEA-induced effects within the striatum have been explained by an inhibitory influence of endogenous $\mathrm{CB}_{1}$ receptor agonists on striatal dopamine receptors (Rodriguez de Fonseca et al, 1998; Giuffrida et al, 1999), concretely $D_{2}$ dopamine receptors, since $D_{2}$ receptor activation enhances AEA release and motor effects of AEA are blocked by quinpirole, $\mathrm{D}_{2}$ receptor antagonist. The data hence supports previous findings indicating that $D_{2}$ dopamine receptor function is negatively affected by AM404. Besides, and of greater importance, AM404 also seems to act through an enhacement of $5-\mathrm{HT}_{1 \mathrm{~B}}$ (but not 5-
$\mathrm{HT}_{1 \mathrm{~A}}$ ) serotonin receptor function in denervated striata, because motor actions of the highly selective $5-\mathrm{HT}_{1 \mathrm{~B}}$ receptor agonist CGS12066B or antagonist GR55562 were either enhanced or reduced, respectively, after coinjection with AM404. Our study also demonstrated that stimulation of striatal $5-\mathrm{HT}_{1 \mathrm{~B}}$ receptors alone reduced parkinsonian asymmetries, supporting the fact that stimulation of these serotonin receptors improves motor function. In this context, it has been reported that $5-\mathrm{HT}_{1 \mathrm{~B}}$ receptors colocalize with $\mathrm{CB}_{1}$ receptors in striatal GABAergic medium spiny neurons (Hermann et al, 2002), pointing to an interrelation between cannabinoid and serotonin activity within striatum, as confirmed for the first time in the present study, and at the level of dorsal striatum, $5-\mathrm{HT}_{1 \mathrm{~B}}$ receptors play a major role regulating serotonin release (Wong et al, 1995). How AM404 interacts with 5- $\mathrm{TH}_{1 \mathrm{~B}}$ receptors deserves further investigation, but modulation of $5-\mathrm{TH}_{1 \mathrm{~B}}$ receptor could be indirect (via an endocannabinoid substance or communication between transduction pathways) or through receptor-receptor interaction. Whatever the mechanism, a positive modulation of $5-\mathrm{HT}_{1 \mathrm{~B}}$ receptor function could account for antiparkinsonian motor effects of AM404. These effects would lead to less disbalance between left and right basal ganglia circuits as indicated by the reduction of amphetamine-induced turning, and amelioration of spontaneous parkinsonian symptoms. It is interesting that NAT enzymatic activity was reduced in denervated striata, likely as a homeostatic mechanism tending to enhance dopamine release. Although AM404 would enhance striatal AEA availability in the biophase thereby reducing dopamine neurotransmission (Giuffrida et al, 1999; Beltramo et al, 2000; Gubellini et al, 2002), this cannabinoid ligand seems to exert antiparkinsonian effects likely through a different mechanism: positive modulation of $5-\mathrm{HT}_{1 \mathrm{~B}}$ receptor function. Functional effects of AM404 validates endocannabinoid deactivation (particularly transport) as a target for anti-parkinsonian therapy.

\section{ACKNOWLEDGEMENTS}

This study was supported by grants to EFE from Spanish Ministerio de Ciencia y Tecnologia (SAF2002-1689), Laboratorios Dr. Esteve (Barcelona), Plan Andaluz de Investigacion (CVI-127), and Plan Nacional sobre drogas, and to FRF from Spanish Ministerio de Ciencia y Tecnologia (SAF20000101), FIS (2000/0654), and RED CIEN C03/06. RED 'Trastornos adictivos' (G03/005) from FIS and Acciones Coordinadas (Junta de Andalucia) supported both EFE and FRF.

\section{REFERENCES}

Baker D, Pryce G, Croxford JL, Brown P, Pertwee RG, Makriyannis A et al (2000). Cannabinoids control spasticity and tremor in a multiple sclerosis model. Nature 404: 84-87.

Beltramo M, Rodriguez de Fonseca F, Navarro M, Calignano A, Gorriti MA, Grammatikopoulos G et al (2000). Reversal of dopamine $\mathrm{D}_{2}$ receptor responses by an anandamide transport inhibitor. J Neurosci 20: 3401-3407.

Beltramo M, Stella N, Calignano A, Lin SY, Makriyannis A, Piomelli D (1997). Functional role of high-affinity anandamide 
transport, as revealed by selective inhibition. Science 277: 1094-1097.

Bisogno T, MacCarrone M, De Petrocellis L, Jarrahian A, FinazziAgor A, Hillard C et al (2001). The uptake by cells of 2arachidonoylglycerol, an endogenous agonist of cannabinoid receptors. Eur J Biochem 268: 1982-1989.

Cadas H, Gaillet S, Beltramo M, Venance L, Piomelli D (1996). Biosynthesis of an endogenous cannabinoid precursor in neurons and its control by calcium and cAMP. J Neurosci 16: 3934-3942.

Cadas H, di Tomaso E, Piomelli D (1997). Occurrence and biosynthesis of endogenous cannabinoid precursor, $\mathrm{N}$-arachidonoyl phosphatidylethanolamine, in rat brain. J Neurosci 17: 1226-1242.

Cadogan AK, Alexander SPH, Boyd EA, Kendall DA (1997). Influence of cannabinoids on electrically evoked dopamine release and cAMP generation in the rat striatum. J Neurochem 69: 1131-1137.

Cenci MA, Whishaw IQ, Schallert T (2002). Animal models of neurological deficits: how relevant is the rat? Nat Neurosci Rev 3: 574-579.

Compton DR, Martin BR (1997). The effects of the enzyme inhibitor phenylmethylsulfonyl fluoride on the pharmacological effect of anandamide in the mouse model of cannabimimetic activity. J Pharmacol Exp Ther 283: 1138-1143.

Consroe P (1998). Brain cannabinoid systems as targets for the therapy of neurological disorders. Neurobiol Dis 5: 534-551.

Desarnaud F, Cadas H, Piomelli D (1995). Anandamide amidohydrolase activity in rat brain microsomes. Identification and partial characterization. J Biol Chem 270: 6030-6035.

Di Marzo V, Hill MP, Bisogno T, Crossman AR, Brotchie JM (2000). Enhanced levels of endogenous cannabinoids in the globus pallidus are associated with reduction in the movement of an animal model of Parkinson's disease. FASEB $J$ 14: $1432-1438$.

Espejo EF, Montoro RJ, Armengol JA, Lopez-Barneo J (1998). Cellular and functional recovery of parkinsonian rats after intrastriatal transplantation of carotid body cell aggregates. Neuron 20: 197-206.

Ferrer B, Asbrock N, Kathuria S, Piomelli D, Giuffrida A (2003). Effects of levodopa on endocannabinoid levels in rat basal ganglia: implications for treatment of levodopa-induced dyskinesias. Eur J Neurosci 18: 1607-1614.

Fornaguera J, Carey RJ, Huston JP, Schwarting RKW (1994). Behavioral asymmetries and recovery in rats with different degrees of unilateral striatal dopamine depletion. Brain Res 664: 178-188.

Fride E, Barg J, Levy R, Saya D, Heldman E, Mechoulam R et al (1994). Low doses of anandamide inhibit pharmacological effects of 9-tetrahydrocannabinol. J Pharmacol Exp Ther 272: 699-707.

Giuffrida A, Parsons LH, Kerr TM, Rodriguez de Fonseca F, Navarro M, Piomelli D (1999). Dopamine activation of endogenous cannabinoid signaling in dorsal striatum. Nat Neurosci 2: 358-363.

Glaser ST, Abumrad NA, Fatade F, Kaczocha M, Studholme KM, Deutsch DG (2003). Evidence against the presence of an anandamide transporter. Proc Natl Acad Sci USA 100: 4269-4274.

Glass M, Brotchie JM, Maneuf YP (1997). Modulation of neurotransmission by cannabinoids in the basal ganglia. Eur $J$ Neurosci 9: 199-203.

Glennon RA, Naiman NA, Pierson ME, Titeler M, Lyon RA, Weisberg E (1988). NAN-190: an arylpiperazine analog that antagonizes the stimulus effects of the 5-HT1A agonist 8hydroxy-2-(di-propylamino)tetralin (8-OH-DPAT). Eur J Pharmacol 154: 339-341.

Gubellini P, Picconi B, Bari M, Battista N, Calabresi P, Centonze D et al (2002). Experimental parkinsonism alters endocannabinoid degradation: implications for striatal glutamatergic neurotransmission. J Neurosci 22: 6900-6907.

Hansen HS, Moesgaard B, Petersen G, Hansen HH (2002). Putative neuroprotective actions of $\mathrm{N}$-acyl-ethanolamines. Pharmacol Ther 95: 119-126.

Herkenham M, Lyn AB, De Costa BR, Richfield EK (1991). Neuronal localization of cannabinoid receptors in the basal ganglia of the rat. Brain Res 547: 267-274.

Herkenham M, Lynn AB, Little MD, Johnson MR, Melvin LS, de Costa BR et al (1990). Cannabinoid receptor localization in brain. Proc Natl Acad Sci USA 87: 1932-1936.

Hermann H, Marsicano G, Lutz B (2002). Coexpression of the cannabinoid receptor type 1 with dopamine and serotonin receptors in distinct neuronal subpopulations of the adult mouse forebrain. Neuroscience 109: 451-460.

Kirik D, Rosenblad C, Björklund A, Mandel RJ (2000). Long-term rAAV-mediated gene transfer of GDNF in the rat Parkinson's model: intrastriatal but not intranigral transduction promotes functional regeneration in the lesioned nigrostriatal system. J Neurosci 20: 4686-4700.

Lastres-Becker I, Cebeira M, de Ceballos ML, Zeng BY, Jenner P, Ramos JA et al (2001). Increased cannabinoid $\mathrm{CB}_{1}$ receptor binding and activation of GTP-binding proteins in the basal ganglia of patients with Parkinson's syndrome and of MPTPtreated marmosets. Eur J Neurosci 14: 1827-1832.

MacLean MR, Clayton RA, Templeton AG, Morecroft I (1996). Evidence for 5-HT1-like receptor-mediated vasoconstriction in human pulmonary artery. $\mathrm{Br} J$ Pharmacol 119: 277-282.

Marshall JF (1979). Somatosensory inattention after dopaminedepleting intracerebral 6-OHDA injections: spontaneous recovery and pharmacological control. Brain Res 177: 311-324.

Middlemiss DN, Fozard JR (1983). 8-hydroxy-2-(di-propylamino)tetralin discriminates between subtypes of the 5-HT1 recognition site. Eur J Pharmacol 90: 151-153.

Neale RF, Fallon SL, Boyar WC, Wasley JW, Martin LL, Stone GA et al (1987). Biochemical and pharmacological characterization of CGS 12066B, a selective serotonin-1B agonist. Eur J Pharmacol 136: $1-9$.

Paxinos G, Watson C (1997). The Rat Brain in Stereotaxic Coordinates. Academic Press: Sydney.

Pertwee RG (1999). Pharmacology of cannabinoid receptor ligands. Curr Med Chem 6: 635-664.

Rodriguez de Fonseca F, Del Arco I, Martín-Calderón JL, Gorriti MA, Navarro M (1998). Role of the endogenous cannabinoid system in the regulation of motor activity. Neurobiol Dis 5: 483-501.

Rodriguez de Fonseca F, Martin-Calderon JL, Mechoulam R, Navarro M (1994). Repeated stimulation of $D_{1}$ dopamine receptors enhances (-)-11-hydroxy-delta8-tetrahydrocannabinol-dimethyl-heptyl-induced catalepsy in male rats. Neuroreport 5: 761-765.

Rodriguez de Fonseca F, Navarro M, Gomez R, Escuredo L, Nava F, $\mathrm{Fu} \mathrm{J}$ et al (2001). An anorexic lipid mediator regulated by feeding. Nature 414: 209-212.

Romero J, Berrendero F, Perez-Rosado A, Manzanares A, Rojo A, Fernandez-Ruiz JJ et al (2000). Unilateral 6-hydroxydopamine lesions of nigrostriatal dopaminergic neurons increased $\mathrm{CB}_{1}$ receptor mRNA levels in the caudate-putamen. Life Sci 66: 485-494.

Sañudo-Peña MC, Patrick SL, Khen S, Patrick RL, Tsou K, Walker JM (1998). Cannabinoid effects in basal ganglia in a rat model of Parkinson's disease. Neurosci Lett 248: 171-174.

Sañudo-Peña MC, Patrick SL, Pastrick RL, Walker JM (1996). Effects of intranigral cannabinoids on rotational behavior in rats: interactions with the dopaminergic system. Neurosci Lett 206: $21-24$. 
Sañudo-Peña MC, Romero J, Seale GE, Fernández-Ruiz JJ, Walker JM (2000). Activational role of cannabinoids on movement. Eur J Pharmacol 391: 269-274.

Schwarting RKW, Huston JP (1996). The unilateral 6-hydroxydopamine lesion model in behavioural brain research. Analysis of functional deficits, recovery and treatments. Prog Neurobiol 50: 275-331.

Seeman P, Van Tol HH (1994). Dopamine receptor pharmacology. Trends Pharmacol Sci 15: 264-270.

Stricker EM, Zigmond MJ (1986). Brain monoamines, homeostasis, and adaptive behaviors. In: Mountcastle VB, Bloom F, Geiger SR (eds). The Nervous System: Neurophysiology. Waverly Press: Baltimore. pp 677-700.

Sullivan RM, Talangbayan H, Einat H, Szechtman H. (1998). Effects of quinpirole on central dopamine systems in sensitized and nonsensitized rats. Neuroscience 83: 781-789.

Surmeier DJ, Song WJ, Yan Z (1996). Coordinated expression of dopamine receptors in neostriatal medium spiny neurons. J Neurosci 16: 6579-6591.
Tsou K, Brown S, Sañudo-Peña MC, Mackie K, Walker JM (1998). Immunohistochemical distribution of cannabinoid $\mathrm{CB}_{1}$ receptors in the rat central nervous system. Neuroscience 83: 393-411.

Ungerstedt U, Arbuthnott GW (1970). Quantitative recording of rotational behavior in rats after 6-hydroxydopamine lesions of the nigrostriatal dopamine system. Brain Res 24: 486-493.

Wong PT, Feng H, Teo WL (1995). Interaction of the dopaminergic and serotonergic systems in the rat striatum: effects of selective antagonists and uptake inhibitors. Neurosci Res 23: $115-119$.

Zimmer A, Zimmer AM, Hohmann AG, Herkenham M, Bonner TI (1999). Increased mortality, hypoactivity, and hypoalgesia in cannabinoid $\mathrm{CB}_{1}$ receptor knockout mice. Proc Natl Acad Sci USA 96: 5780-5785.

Zygmunt PM, Chuang H, Movahed P, Julius D, Hogestatt ED (2000). The anandamide transport inhibitor AM404 activates vanilloid receptors. Eur J Pharmacol 396: 39-42. 